\title{
Tensions beneath the surface- the Swedish mainstream parties and the immigration issue
}

\begin{abstract}
The main focus of this article is on how the Swedish mainstream parties on the centre-left and the centre-right have dealt with the immigration issue. After brief overviews of trends in immigration and public opinion, the history of immigration in Swedish politics since the 1980s is discussed. It is argued that the 2002 election campaign was of pivotal importance for a number of reasons; most importantly because it politicised labour immigration. The main empirical part consists of a qualitative content analysis of 25 election manifestos from 2002, 2006 and 2010. The analysis shows a clear difference between the mainstream parties and the Sweden Democrats. More importantly, there are differences also among the mainstream parties, in terms of the relative amount of space devoted to immigration as well as substantive content. This is most evident on the centre-left. There is more coherence on the centre-right, but also here underlying tensions can be detected. Thus the issue of immigration has the potential to destabilise the two main political blocs, as well as the entire party system.
\end{abstract}

Keywords: Migration policy, Labour immigration, Swedish politics, party systems, election manifestos. 


\section{Introduction}

The economic left-right dimension has proved resilient in Swedish politics. Environmental issues began to make an impact in the 1980s, but after initial difficulties the established parties adapted to them relatively successfully. Immigration has proved more problematical. It is emotive, and tends to polarise opinion, which makes it both difficult to handle pragmatically and susceptible to populist exploitation. Immigration cuts across both the economic left-right as well as the GAL/TAN dimensions, because it touches on a wide range of policy fields, such as the economy, labour market, welfare system, education, culture, law and order, etc. (compare Hooghe et al 2002; 2010). This can lead to dilemmas for mainstream parties to the left as well as right, especially if a distinction is made between different kinds of immigration. Centre-left parties like to portray themselves as opponents of ethnic intolerance and defenders of international solidarity, but are prone to a protectionist position on labour market issues. Centre-right parties, on the other hand, see themselves as champions of individual freedom and the right to move across borders, but also as defenders of national values. Both sides operate within a meta-ideological frame sometimes referred to as "political correctness", but are subject to internal as well as external pressures towards more restrictive immigration policies.

This article has two main parts. First, it outlines some key events in the Swedish immigration debate. Second, it provides a content analysis of the parties' election manifestos from 2002, 2006 and 2010. In the process, attempts will be made to test the three hypotheses presented in the introductory article. All eight parties represented in parliament after the 2010 election will be analysed, including the Sweden Democrats (SD), although the latter party was not in parliament before 2010. Emphasis, however, will be on the other seven parties, which will be referred to as the mainstream parties. These will, in turn, be separated into two main groups. The centre-left parties comprise the Social Democrats (SAP), the (post-communist) Left Party and the Greens. The centre-right parties are the Moderate (conservative) Party, the People's Party Liberals (referred to as the "Liberal Party" or "Liberals"), the Christian Democrats and the (formerly agrarian) Centre Party.

FIGURE 1 HERE 
As shown in Figure 1, Sweden a country of high immigration. Non-Nordic labour immigration was abolished in 1972, but since the 1980s there has been a steady influx of asylum seekers. The figure reports asylum applications as percentages of the population, which have never reached on per cent in a year. The proportions are still high compared to many other countries, and over the 1985-2013 period Sweden is one of the main asylum recipients in Europe. The absolute numbers (not reported in the figure) reached an early peak of 84,000 in 1992 , followed by a steep but temporary decline. Since 1998 the number has not been below 10,000, and since 2005 not below 20,000. The 2013 figure of 54,000 was the highest since 1992. It goes without saying that the Swedish population has been affected. In the late 1990s nearly eight per cent of the population were born outside the Nordic region (Denmark, Finland, Iceland, Norway and Sweden); in 2013 the proportion had grown to 13 per cent. The most common non-Nordic country of birth in 2013 was Iraq, followed by Poland, the former Yugoslavia, Bosnia-Herzegovina and Somalia.

Research by Demker (2012) indicates a long-term development towards less negative attitudes to refugee immigration. Without exception, however, Demker's data show clear pluralities of 'refugee-negative' responses throughout the 1990-2011 period. In other words, immigration is by no means uncontroversial in Sweden. The trend may well have been towards less negativity, but the mainstream parties cannot be relaxed about the situation. This is also reinforced by the levels of trust in the parties' refugee and immigration policies. Election Studies data suggest that none of the mainstream parties is highly trusted in these areas. In relative terms the Social Democrats and Liberals are the most trusted parties, but both are significantly more trusted in several other issue areas. (Holmberg \& Oscarsson 2004:132; Oscarsson \& Holmberg 2013:209).

\section{The immigration issue in Swedish politics - some key events}

For many years, immigration was not a politicised issue. In December 1989, however, a Social Democratic government tightened Swedish asylum policy. In essence, the decision was to give asylum only to those who were classed as refugees according to the UN convention on refugees from 1951. This meant that "de facto refugees", including those who had refused military service, were no longer eligible for asylum, unless they could claim "special needs". It was a government decision, not voted on in parliament, but subject to a parliamentary debate. Moderate and Centre Party representatives supported the decision, 
while speakers from the Liberals, Greens and the then Left Party Communists were critical (Abiri 2000:15; Riksdag minutes 1989/90:46; section 9). The decision was also subject to much media debate, and criticism from pro-immigration campaign groups. At the time of the 1989 decision, no immigration-critical party of any significance existed. In 1991, however, the newly formed New Democracy (NyD) entered parliament. Immigration criticism was part of the NyD agenda from the outset, and the rhetoric intensified some time after the parliamentary entry (Rydgren 2006:54). The other parties responded with unanimous condemnation. If anything, the arrival of $\mathrm{NyD}$ on the scene seemed to force the mainstream parties closer together. Disagreements about immigration policy, which had surfaced after the government decision in December 1989, were toned down.

A centre-right minority coalition, which took office after the 1991 election, withdrew the restrictions introduced in 1989. This was a concession to the Liberals, who had been the only party to take the debate to New Democracy in the 1991 campaign, and in general had an immigration-tolerant profile. The Liberals were also put in charge of migration in the new government. This soon turned out to be a poisoned chalice, however, with unprecedented numbers of asylum seekers arriving from the Balkan countries. The Liberals, who in opposition had criticised the SAP government for being too restrictive, were soon subject to similar criticism (Abiri 2000:19). Decisions in 1992 and 1993 were taken to stem the influx of Balkan refugees, essentially by making entry into Sweden subject to visa for citizens of the remaining Yugoslavia and, later, Bosnia-Herzegovina. The latter decision was coupled with a general "amnesty" for most of the circa 40,000 Bosnian refugees waiting to have their applications processed (Abiri 2000:20). The double-sided character of the decision prompted criticism from all sides, but it did have the intended effect. The numbers of asylum applications sank in the second half of the 1990s.

The Social Democrats returned to power in 1994, and introduced a new overhaul of refugee policy, which took effect in 1997. According to the government, the changes were intended to remove ambiguities in the system, but critics argued that this in practice amounted to a toughening of the regulations. The reforms included more restrictive criteria for asylum, along very similar lines to the restrictions introduced in December 1989. In addition, the criteria for family reunification were tightened. This time, however, the reforms were decided by parliament, and made into law. The government bill was supported by the Moderate, and in part also Centre, parties (Abiri 2000:22ff). New Democracy had been annihilated in the 
1994 election, but back in office the Social Democratic government continued what many saw as a tough line on immigration (Rydgren 2004). Without too much simplification, the positions in the 1990s were that SAP and the Moderates pursued the most restrictive policies. These have been Sweden's two biggest parties since the late 1970s, and together they have for many years commanded a comfortable parliamentary majority. On economic issues they are traditional adversaries, and the fact that they were close together in any issue area was not something either party sought to publicise. The Centre Party was in an intermediate position, while the Christian Democratic, Green and Left parties favoured more generous immigration policies. This also applied to the Liberals, despite the party's difficult experience as responsible for government migration policy 1991-1994.

Immigration received limited attention in the 1998 election. A month and a half before the 2002 election, however, the Liberal Party presented an immigration and integration policy package, which transformed the party's earlier image as "soft" on immigration. Arguably the most discussed proposal was the introduction of a language test as a criterion for Swedish citizenship. Such a requirement had in fact existed earlier, but not been rigorously applied and was dropped in the early 1980s (Rooth \& Strömblad 2008:33). The proposals also included measures against immigrant unemployment. Immigrants who could present an offer of employment would immediately be given a temporary residence permit, which would become permanent after five years. In the meantime, however, the immigrant would not be eligible for the full range of welfare provisions, and would be forced to leave if the employment was lost (Dagens Nyheter, 2002b; Widfeldt 2003). In other words, labour immigration (which in practice had been abolished by an SAP government in the early 1970s) was a key part of the Liberal package.

The proposals led to an intense debate. It must be remembered that they were not designed to reduce immigration - the consequences could just as well be increased immigration. Nevertheless, the Liberals set a number of criteria for the acceptance and retention of immigrants, which gave the party a new image of toughness. It may, therefore, be more accurate to say that the package amounted to more generous immigration policies, but stricter integration policies (compare Hinnfors et al. 2012, who distinguish between entry policy and integration policy). In the debate, however, this distinction tended to be overlooked and there is much to suggest that the proposals went down well with immigration-sceptical voters. This led to rather mixed feelings in the party, and in other election material the toughened 
demands on immigrants were combined with denouncements of racism and intolerance, expressions of support for multiculturalism and advocacy of a more generous refugee policy (Liberal Party, 2002b).

The Liberals had struggled in the polls before the 2002 election, but the ratings improved after the immigration and integration policy package had been presented. In the election the party almost trebled its number of seats, and came close to overtaking the Moderates as the second biggest party. Available evidence suggests that the immigration and integration policy package was, at least, a contributory factor to the Liberal success (Holmberg \& Oscarsson 2004:126ff). It also meant that immigration and integration became important campaign issues. To an extent, however, this applied to the media and the political elites rather than voters in general. As can be seen from Table 1 below, voters' prioritisation of immigration did increase in 2002, but it was still behind health care, education and pensions/elderly care. Other data sources indicate that voters gave immigration/integration issues even lower priority (Widfeldt 2003:781).

The 2002 election remains the most centred on immigration and integration to date. It is worth remembering that no immigration-critical party posed any serious challenge at the time. New Democracy had been irrelevant since 1994. The Sweden Democrats made some gains in the 2002 election, but were still far from a national breakthrough. Thus, the decision by the Liberals to position themselves as "hardliners" on immigration policy was not driven by any perceived threat from an outsider party. A possible background factor could be the terrorist attacks on the USA a year earlier, but warnings against terrorism or religious extremism did not feature in the party message. Another possible influence could be the liberal sister party Venstre in Denmark, which had pursued restrictive immigration as well as integration policies after taking office in 2001. Against this it could be argued that the Swedish Liberals did not follow the Danish restrictions on refugee immigration. In addition, the Swedish party was - and is - very critical of Venstre's support party, the Danish People's Party. Indeed, the Swedish Liberal leader Lars Leijonborg participated in a heated TV debate with Danish People's Party leader Pia Kjærsgaard in May 2002 (Dagens Nyheter, 2002a). Rather, it seems that the Liberal repositioning was driven by negative opinion poll ratings. The strategy worked very well in the short term, and the election was a resounding success. The effect did not last, however - the Liberals lost votes in 2006 and 2010. 
The longer-term significance of the 2002 election could be summarised in three points. First, the Liberal Party changed its profile on immigration. Although, as we have seen, the party's position cannot straightforwardly be termed as restrictive, this was the perception among the voters, and it marked a clear contrast to the public profile the party had previously adopted. The substantively new element was that the openness to immigration remained was combined with demands, where immigrants able to quickly integrate into the labour market are rewarded. The party itself summarised the new position with the catchword "clarity" (for examples, see Backman 2006; Haddad 2012). It fits with a broader image of the party as "clear" in other areas, for example emphasising knowledge and discipline in schools. Second, the 2002 election was the first in which a mainstream party consciously and publicly emphasised immigration and integration issues. Other parties had done so at the local level, and individuals in several parties had voiced concerns about immigration. As discussed, restrictions on immigration had been government policy already in the 1980s. No party had, however, previously adopted a public profile characterised by "clarity" the way the Liberals did in 2002. Third, the 2002 election could be seen as the starting point for the distinction between labour and refugee immigration in the political debate. As such, this distinction was not new - the Moderates had for many years advocated more openness to labour immigration (Odmalm 2011:14f). It had not, however, been politicised to nearly the same extent, and never featured as prominently in the election debate. The Liberal Party did not seek to politicise immigration in general - what they did was to politicise integration and labour immigration. In these respects, the long-term significance of the 2002 election was considerable.

The politicisation of labour immigration opened SAP to accusations of protectionism. The counter-argument was that labour immigration was used as an underhand device to undermine the Swedish model of the labour market, but SAP was very much on the defensive in the debate. The party was also criticised for bringing welfare concerns into the discussion. In 2004 when ten, mostly East European, countries were about to join the EU, SAP Prime Minister Göran Persson expressed concern about an influx of East European immigrants seeking to exploit the welfare system (Dagens Nyheter, 2004). The SAP government proposed transitional restrictions on immigration from the new EU countries, but following a breakdown of negotiations with the centre-right parties, Sweden became one of the few existing EU countries not to introduce such restrictions (Hinnfors et al 2012:592). In the debate about labour immigration the Green Party, which has a history of pragmatism on 
labour market issues, became pivotal. In November 2008, the Greens reached an agreement with the centre-right government, which had taken office in 2006, to allow labour immigration (Riksdag \& Departement 2008). The Green support was strictly speaking not necessary, as the centre right coalition commanded an outright majority between 2006 and 2010, but it made the reform less vulnerable to future majority shifts.

The co-operation between the Greens and the centre-right government continued with an agreement on refugee policy, announced in March 2011. The 2011 agreement contained relatively few concrete policy reforms, but did include more generous treatment of "paperless" refugees (i.e. without identity documents), for example the right to health care and the possibility for affected children to attend school. It also contained measures to facilitate family reunions for paperless refugees (Dagens Nyheter, 2011a; 2011b). An essential part of the background was that the Sweden Democrats had entered parliament in 2010, and were in a pivotal position between the two blocs. The agreement between the government and the Greens thus prevented SD from potential influence in their profile issue.

As should be apparent from the above, immigration has only rarely been high on the political agenda. This is also borne out in Table 1 below, which reports the priority of immigration, relative to sixteen other issue/problem areas for every year between 1987 and 2011. Despite being taken from different data source, as well as being calculated and reported in a different way, the data presented here are largely in line with the patterns reported by Odmalm (2011:1076). The proportions citing immigration as an important issue have fluctuated considerably over the years. In the non-election years 1990, 1992 and 1993, for example, immigration had very high priority - the 26 per cent citing immigration in 1993 is the highest proportion in the whole period.

\section{TABLE 1 ABOUT HERE}

The proportions then dropped sharply, but increased again in the 2000s. There have been significant fluctuations also after 2000. There is a tendency for immigration to have become somewhat more prioritised after the turn of the century. In contrast to the 1990s, however, the peaks after 2000 have been in election years; the above-discussed 2002, and 2010, when the Sweden Democrats broke through. Still, not even in those peak years immigration has been the top priority among the Swedish public. Except for 1993, never more than 1 in 5 
respondents have put immigration among the up to three most important issues or problems. In the 2000s, the proportions have varied between 11 and 20 per cent. The average across the 1987-2011 period is 14 per cent; the eighth highest of the 17 issue areas on which Table 1 is based. The highest overall averages are employment (32 per cent), health (28 per cent) and environment (23 per cent). Between 2000 and 2011 immigration was the sixth most prioritised issue. Thus, while immigration is not a top priority among voters, it is not an insignificant issue.

\section{The Swedish parties and immigration}

In this section the Swedish parties' treatment of immigration in the 2002, 2006 and 2010 elections will be analysed. The source will be the election manifestos which, although they do not provide an exhaustive account of a party's positions and policies in every area, can be taken as valid indicators of the priority a party gives to a particular policy area, and the party's key policy aims and positions in that area. ${ }^{1}$

\section{TABLE 2 HERE - ENTIRE PAGE IN LANDSCAPE FORMAT}

The Sweden Democrats is the only party to have devoted more than ten per cent of their election manifestos to immigration. Among the other parties, the greatest emphasis can be found in the Liberals and the Greens. The trends over time are declining for SAP and the Left Party, while the Green Party proportions are more stable. Across the centre-left in general, however, the overall decline is unambiguous. The trend for the centre-right is less clear-cut. The Christian Democrats made only brief references to immigration in 2002 and 2006, but the emphasis increased in 2010. There is an increase over time also in the Liberal Party, although it is not continuous. The Centre Party displays very low levels in all three elections. The overall centre-right trend is curvilinear or increasing, depending on what is included, but

\footnotetext{
${ }^{1}$ Swedish parties sometimes present joint manifestos with parties they intend to partner in government; either instead of their own manifesto, or in addition to it. Here 25 manifestos, joint and separate, are analysed. The prioritisation of immigration has been measured as the number of words in a manifesto with relevance to immigration and integration. Also references to ethnic discrimination, racism, etc., have been included. The unit of analysis is the words, but only whole sentences are included in the word count. Sections with immigration, refugee policy, etc., in the title have been included in their entirety.
} 
the contrast to the unambiguous decline among the centre-left parties is clear. Election by election, the average was significantly higher for the centre-left than for the centre-right in 2002, but this was reversed in 2006. In 2010 neither of the centre-left or centre-right manifestos devoted much space to immigration, but the proportion was somewhat higher in the latter document. The sizes of the differences between the centre-left and centre-right in 2006 and 2010 depend on what is included in the comparison, but the main observation remains - the centre-left parties devoted more space to immigration in 2002 , but the centreright parties did so in 2006 and 2010.

Moving on to the substantive content, the fourth and fifth columns in Table 2 report whether a party seeks to change immigration policy in either direction. The criteria used are subjective to the respective parties, and relative to the situation as they saw it when the manifestos were written. Thus, advocacy of a more generous policy is indicated with a plus sign, while proposals of a less generous policy are indicated with a minus sign. Mere commitments to a "generous" or "humane" policy have been entered as neutral, symbolized with a zero, because no change is proposed. Unsurprisingly, the only party to argue that refugee immigration should be reduced is the Sweden Democrats. Advocacy of a more generous refugee policy is found mainly in the Left and Green parties. In 2002 the Left Party argued that "Sweden should have a more generous refugee policy" (Left Party 2002). This, the party argued four years later, could be achieved by abandoning the Treaty of Schengen (Left Party 2006). In 2010, however, the Left Party is less specific: "our future vision is a society free of racism, and that Sweden has a humane and legally secure refugee policy which meets international conventions". This has been entered in the table as neutral, as it does not explicitly advocate more generosity (Left Party, 2010). The Greens advocate more a more generous refugee policy in each manifesto, although with variations in the concrete proposals. In 2002 and 2006 the party proposed an amnesty to asylum seekers who have waited more than one year (Green Party, 2002; 2006). In 2010 the party argued for a more generous refugee policy in less specific terms, but in addition proposed an amnesty for paperless refugees (Green Party, 2010). The SAP reaction to the latter proposal was sceptical (Dagens Nyheter, 2010). Against this background, the centre-left manifesto presented in late August, some 2.5 weeks before the election, could be seen as a concession to the Greens. It did not go as far as the Greens had preferred, but it included a pledge to "strengthen" the protection of women, children and sexual minorities. This has been interpreted as meaning that the criteria 
for such refugees should be made more generous, and entered as a plus sign in Table 2 (Centre-left parties, 2010).

The Social Democratic position has been influenced by the fact that the party was in government, and thus directly responsible for refugee policy, for long periods. In 2002, when the party was, and stayed, in office, the SAP manifesto argued that the refugee policy should be human, legally secure (rättssäker) and characterised by solidarity. The party does say that conditions for refugee children without parents should be improved, but without further specifications. Emphasis in the 2002 document was on faster and legally more secure handling of asylum applications, but without any specified commitment to a more generous policy, and has therefore been entered as neutral in Table 2 (Social Democrats, 2002). This position was largely repeated in 2006 (Social Democrats, 2006). The SAP document from 2010, however, makes no reference to refugee immigration. Like SAP, the centre-right parties are reluctant to advocate more generous asylum policies. The Christian Democrats proposed in 2010 that the rights for children in the asylum process should be strengthened, and that local councils should be obliged to accept child refugees who arrive on their own (Christian Democrats, 2010). In the same year the Liberals advocated rights to health care and education for paperless refugees and their children (Liberal Party, 2010). The other centre-right manifestos, separate by party as well as the four-party documents from 2006 and 2010, have similarities with the SAP documents from 2002 and 2006, with general commitments to the acceptance and human treatment of refugees, but without proposals to make the criteria more generous.

It is the centre-right parties that mention labour immigration, and always in positive terms. The joint centre-right manifestos from 2006 and 2010, as well as the separate manifestos from the Centre and Liberal parties, explicitly advocate labour immigration (Centre Party, 2006; 2010; Liberal Party, 2002a; 2010). The 2006 Liberal manifesto has a long section about integration, with proposals regarding immigrants and employment, but no specific reference to labour immigration. The fact that labour immigration had been re-introduced during the 2006-2010 parliamentary term meant that the centre-right parties no longer advocated a more generous labour immigration policy; rather they argued for the retention of the recently introduced reform. This has still been entered as positive in Table 2. The Green Party, which supported the labour immigration reform by the centre-right government, does not mention this in any of the analysed manifestos. Neither does SAP or the Left Party, both of whom are 
of course against the reform. The issue is also not mentioned in the centre-left manifesto from 2010.

The 2002 election highlighted demands, the penultimate column in Table 2 . The view that immigrants should be encouraged to work instead of relying on benefits was not as such new. Nor was it only put forward by the Liberals; the Moderate manifesto from the same year stated that the party does not "...accept a demand-free dependency on benefits, where the passivity of welfare authorities enable immigrants to over-utilise the welfare systems" (Moderate Party, 2002). Still, the 2002 election can be seen as a starting point, from where the "clarity" approach would be a common, recurring and explicit theme for the centre-right parties. The Liberals advocate various forms of demands in all three years; "jobs instead of benefits" (Liberal Party, 2002a), an obligation for immigrants to participate in training and development programmes (Liberal Party, 2006) and the statement that "everyone has the same responsibility to fend for themselves, irrespective of origin" (Liberal Party, 2010). The Centre Party manifestos from 2002 and 2006 also contain demands, while the Christian Democratic documents only do so once, in 2010. In the latter case the demands are fairly toned-down, for example that everybody in Sweden should have "the same rights, obligations and opportunities", and the proposal of introductory information about the Swedish society for newly arrived immigrants, according to individual needs and abilities. These guarded wordings explain why the "yes" entry in the table has been put in brackets (Christian Democrats, 2010).

The joint centre-right manifestos from 2006 and 2010 highlight alleged integration problems, but contain no explicit demands. The 2006 centre-right manifesto actually speaks against "more control of, or reduced benefits for, immigrants". At the same time, the document argued that persons born outside Sweden are over-represented among criminals, which is "a social problem that must be taken seriously". The proposed remedy was focused on the social causes of crime. The document also argued that foreign citizens who have committed serious crimes should in principle be expelled, but did not propose any formal changes (Centre-right parties, 2006). The 2010 centre-right document does not mention immigrant crime, but highlights immigrant unemployment. The proposed counter-measures are not phrased as demands, but rather as improved opportunities to get work, such as improved language training and increased incentives for employers to hire immigrants (Centre-right parties, 2010). Thus, although the 2006 and 2010 documents highlight what is perceived as 
integration problems the remedies are not formulated as demands, and have therefore been entered in Table 2 as "no" demands.

On the centre-left, there is a divide between the Social Democrats and the other two parties. The SAP document from 2006 proposes a personalised establishment contract "based on clear rights and obligations" for all newly arrived refugees (Social Democrats, 2006). There is, however, no such proposal, or any kind of demand, in the SAP document from 2010, or in the joint centre-left manifesto from the same year. Both the latter documents state that it should be made easier for newly arrived immigrants to enter the labour market; the centre-left manifesto adds that language skills are of key importance (SAP, 2010; Centre-left parties, 2010). In this respect, therefore, the SAP and joint centre-left manifestos from 2010 have similarities with the centre-right documents from 2006 and 2010. They all propose measures to improve the integration of immigrants to the labour market, but the proposed remedies are formulated as improved opportunities rather than demands. The Sweden Democrats have several demands in each manifesto. Immigrants without the need for protection, or the capacity to support themselves, will be returned to their countries of origin (Sweden Democrats, 2002; 2006); it is also stated that "immigrants should adapt to the Swedish society and not vice versa" (Sweden Democrats, 2006; 2010).

The final column in Table 2 reports general value statements about immigration. These are statements for or against immigration, not based on material costs or benefits, but as a positive or negative value in and of itself. Such value statements are most common among the centre-right parties. The joint centre-right manifestos, for example, state that "we want to live in a society characterised by togetherness and diversity" (Centre-right parties, 2006), and that migrants "contribute with their experiences and knowledge in the recipient countries" (Centre-right parties, 2010). Elsewhere there is a tendency that parties making demands on immigrants also tend to make positive value statements about immigration. The Liberals, for example, argued in 2006 that "international solidarity and a humane refugee policy are cornerstones in the social liberal tradition"; and in 2010 that Sweden has been enriched by its openness to the surrounding world (Liberal Party, 2006; 2010). The Centre Party argues that "immigration contributes to an open and innovative society" (Centre Party, 2010), while the Christian Democrats state that "meetings between people of different backgrounds make Sweden better" (Christian Democrats, 2010). 
Another pattern is that parties with strong views on immigration, either way, seem to consider value statements as superfluous. The Left and Green party documents contain several statements against racism and discrimination, but no principled statements for immigration. Conversely, only one out of the three analysed Sweden Democrat documents contains principled statements against immigration. The 2002 document is brief, basically containing the statement that immigration has been too high. In 2006, the party argues that immigration has caused "enormous economic, social and cultural problems", and that multiculturalism is a serious threat against the cohesion that is a condition for the Swedish welfare model based on solidarity. This rhetoric is significantly toned down in 2010, when the SD manifesto contains a number of restrictive policy proposals, but the value statements are guarded, and not even unidirectional. The party argues that freedom and openness are obvious Swedish values, but also that the Swedish cultural heritage, and the right for Swedes to develop their own culture on their own conditions, should be protected (Sweden Democrats, 2010). The SAP manifesto contained fairly far reaching value statements in 2002, but not in 2006 or 2010 (Social Democrats, 2002; 2006; 2010). The centre-left manifesto from 2010 contains no value statements (Centre-left parties, 2010).

To sum up, a number of observations can be made. The first is almost trivial: there is a clear divide between the Sweden Democrats, on the one hand, and the seven other parties, on the other. A second observation concerns the mainstream parties' responses to the rise of SD. For the centre-left parties the trend over time is unequivocal; the relative space devoted to immigration was highest in 2002, when SD was still a fringe party. It sank in 2006, when SD was growing stronger but still some way from a breakthrough. It sank even further in 2010, when the likelihood of an SD breakthrough was high. For the centre-right parties the development over time is less clear-cut, and depends on whether the separate or joint manifestos are taken into account. Comparing the latter documents, however, the relative centre-right emphasis on immigration was lower in 2010 than in 2006. Thus, the response from the mainstream parties to the growth of SD was not to increase their attention to immigration - there is some, albeit not unequivocal, evidence to the contrary. 
Nor can it be argued that the mainstream parties changed their positions on immigration in response to the growth of SD. The view of the Liberal Party has been clear throughout the 2002-2010 period - in principle lauding the benefits from immigration, but with an additional and significant element of demands, or "clarity". The same can, largely, be said of the Centre Party, which devotes less space to immigration than the Liberals, but with similar policy and value positions. The Christian Democrats are more reluctant to make demands on immigrants, and do not explicitly support labour immigration (although the party has stood by the labour immigration reform agreed in 2008). The Moderate Party presented a separate manifesto only in 2002, a document which was similar to the Centre and Liberal manifestos. Also the joint centre-right manifestos from 2006 and 2010 fit with the overall centre-right pattern, in terms of overall outlook as well as policy aims. On the whole, therefore, the centre-right documents are characterised by similarity and stability.

There is more diversity on the centre-left. An obvious example, discussed earlier, is labour immigration, which separates the Greens from the other two centre-left parties. In terms of refugee immigration the odd party out is the Social Democrats, who are also the only centre-left party to have attached demands to the proposed immigration policy. In fact, it is possible to observe a development towards more restrictiveness in the SAP manifestos from 2002 to 2006; positive value statements appear in the former document but not in the latter; while demands appear in the latter but not in the former. This trend could be linked to the fact that support for SD grew between 2002 and 2006, not least in terms of local council seats. On the other hand the SAP document from 2010 - when SD was much stronger - significantly toned down immigration. The analysis of SAP documents is nevertheless largely in line with Hinnfors and colleagues who, on the basis of a more long-term analysis, conclude that "SAP has consistently favoured more restrictive policies", in terms of labour as well as refugee immigration (Hinnfors et al. 2012; quote from page 599). The Left and Green documents display no trends in any direction. Neither party puts any demands on immigrants. The rather watered-down, and brief, passages on immigration in the joint centre-left manifesto from 2010 can thus be interpreted as a sign of underlying tensions among the three centre-left parties.

\section{Conclusion}


It is clear that immigration is a difficult issue for the Swedish mainstream parties. Their self-image as generous is not necessarily insincere as such, but it does hide underlying tensions. This is particularly evident on the centre-left. The Social Democrats are more restrictive than the other two parties on refugee policy. In addition, although it does not show in the election manifestos, the Greens are more liberal than the other two on labour immigration. There is more prima facie coherence on the centre-right, but also here latent divisions can be detected. The analysis of the party manifestos indicate that the Christian Democrats deviate somewhat from the other three on refugee immigration. In the recent public debate there have, furthermore, been indications that the Moderate Party is more restrictive than the other centre-right parties. The Moderate position has also at times threatened to undermine the relations with the Greens (see, e.g., Dagens Nyheter, 2013). In terms of labour immigration, the situation is slightly different. Here, the centre-right parties are united, they have pursued the issue, and they bring it up in their manifestos. The centre-left parties have not done so, even though their policy positions are clear - SAP and the Left Party are opposed, while the Greens are in favour. An obvious reason why the centre-left parties seek to play down the issue is of course that they are split, but it is a difficult issue for them also in other ways. The issue of labour immigration highlights the "Swedish Model" on the labour market, the role of trade unions and the rights and conditions for Swedish workers, and should therefore suit SAP and the Left Party. There are, however, reasons why this is not the case.

One is internal, and applies primarily to SAP. Labour market issues increasingly have an international dimension, and a debate about the Swedish labour market, and its openness to foreign workers and companies, will almost certainly open up old wounds in the EU-divided SAP (compare Woolfson et al., 2010). Second, it will be difficult to confine the debate to the economic left-right dimension. What defenders of the "Swedish model" view as protection of a stable labour market and safe working conditions, critics regard as nationalistic egoism in a globalised world. In such a debate climate, accusations of intolerance and protectionism are never far away, especially as the Sweden Democrats are certain to appear on the same side in the debate as SAP and the Left Party. A third problem is that the Green position makes the battle about labour 
immigration more or less unwinnable for SAP and the Left Party, as the likelihood of a future election producing an outright SAP-Left Party majority is very small. The only possible solution would be to turn to the Sweden Democrats - an unthinkable option for both parties.

The evidence presented gives some, albeit qualified, support for two of the three hypotheses presented in the introductory article to this special issue. The fact that the centre-left parties, who are split on immigration, de-emphasised the issue between 2002 and 2010 is in line with hypothesis 1 (parties emphasise immigration if they agree on the issue) and 3 (parties divert attention away from immigration if they cannot resolve ideological tensions from it). The fact that the centre-right parties did not significantly increase their emphasis on immigration during the same period could be said to point in the same direction. As just mentioned, there are latent inter-party tensions also on the centre-right, although not as serious as on the centre-left. Regarding hypothesis 2 (parties will downplay immigration if they are not trusted by voters on the issue), the evidence is contradictory. Of the two parties with the highest levels of trust on immigration, the Liberals increased their emphasis on the issue over time, while the Social Democrats went in the opposite direction.

It seems clear, therefore, that immigration will continue to cause problems for the mainstream parties. The growth of the Sweden Democrats is a contributory factor, but not the core reason. The underlying tensions about refugee as well as labour immigration can be traced back to when SD was far from being a potent threat. The difference is that it was easier to avoid open conflicts about the issue when there was no SD - the New Democracy interlude was brief. The Sweden Democrats are unlikely to disappear as quickly, and will do what they can to keep immigration on the agenda. The open and latent divisions among the mainstream parties will not go away, and the future political development could mean that they will be increasingly exposed. The implications could be significant, for the individual parties as well as the entire party system. 


\section{BIBLIOGRAPHY}

Abiri, E. (2000) The Changing Praxis of "Generosity"': Swedish Refugee Policy during the 1990s. Journal of Refugee Studies 13(1): 11-28.

Backman, H. (2006) Folkpartiet har en tydlig integrationspolitik. Gefle Daglblad and Arbetarbladet, 3 May. (http://www.folkpartiet.se/vara-politiker/ledamoter-avriksdagen/hans-backman/artiklar/folkpartiet-har-en-tydlig-integrationspolitik/)

Dagens Nyheter (2002a) Arg Leijonborg i dansk debatt. 26 May.

Dagens Nyheter (2002b) Fp ställer språkkrav för att få bli svensk. 4 August, p. A8.

Dagens Nyheter (2004) Persson vill skydda den svenska välfärden. 31 January.

Dagens Nyheter (2010) Dubbla valmanifest riskerar bli ett problem. 17 May, p. 8.

Dagens Nyheter (2011a) SD stängs ute från migrationspolitiken. 4 March, p. 14.

Dagens Nyheter (2011b) Första steget klart i asylpolitiken. 18 September, pp. 8f.

Dagens Nyheter (2013) MP till attack mot M: Obehagliga tongångar. 5 February, p. 10.

Demker, M. (2012) Positiv attityd till invandring trots mobilisering av invandringsmotstånd. In: A. Bergström, L. Weibull \& H. Oscarsson (eds.) I framtidens skugga (SOM-rapport nr. 56). Göteborg: SOM-institutet, pp. 95-105.

Haddad, R. (2012) Roger Haddad (fp): Tydliga krav för bättre integration. Vestmanlands Läns Tidning, 12 October. (http://www.folkpartiet.se/vara-politiker/ledamoter-avriksdagen/roger-haddad/press/roger-haddad-fp-tydliga-krav-for-battre-integration/) 
Hinnfors, J., Spehar, A. and Bucken-Knapp, G. (2012). The Missing Factor: Why Social Democracy can lead to restrictive immigration policy. Journal of European Public Policy 19(4): 585-603.

Holmberg, S. and Oscarsson, H. (2004) Väljare. Svenskt Väljarbeteende under 50 år. Stockholm: Norstedts Juridik.

Hooghe, L. Marks, G. and Wilson, C.J. (2002) Does Left/Right Structure Party Positions on European Integration? Comparative Political Studies 35(8): 965-989.

Hooghe, L., Bakker, R., Brigevitch, A., De Vries, C., Edwards, E., Marks, G., Rovny, J. Steenbergen, M. and Vachudova, M.. (2010) Reliability and Validity of the 2002 and 2006 Chapel Hill Expert Surveys on Party Positioning. European Journal of Political Research 49(7): 867-703.

Odmalm, P. (2011) Political Parties and 'the Immigration Issue': Issue Ownership in Swedish Parliamentary Elections 1991-2010. West European Politics 34(5): 1070-1091.

Oscarsson, H. and Holmberg, S. (2013) Nya svenska väljare. Stockholm: Norstedts Juridik.

Riksdag \& Departement (2008) Sverige åter öppet för arbetskraftsinvandring. 17 November (issue 32), p. 13.

Riksdag minutes (1989/90:46) Retrieved via http://www.riksdagen.se/sv/DokumentLagar/Kammaren/Protokoll/Riksdagens-protokoll-1989904_GD0946/ (accessed 2 June 2014).

Rooth, D.-O. and Strömblad, P. (2008) Språk, krav och medborgarskap. Stockholm: Globaliseringsrådet. Underlagsrapport $\mathrm{nr} \quad 14$ till Globaliseringsrådet. (http://www.government.se/content/1/c6/10/68/31/a8b9fe40.pdf)

Rydgren, J. (2004) Radical Right-wing populism in Sweden and Denmark. Beer Sheva, Israel: Ben Gurion University of the Negev. The Centre for the Study of European Politics and Society Papers, No. 5 (http://hsf.bgu.ac.il/europe/uploadDocs/csepspjr.pdf) 
Rydgren, J. (2006) From Tax Populism to Ethnic Nationalism. Radical Right-Wing Populism in Sweden. New York and Oxford: Berghahn Books.

Weibull, L., Oscarsson, H. and Bergström, A. (2012) Swedish Trends 1986-2011. Göteborg: SOM-rapport 2012:27. (http://www.som.gu.se/digitalAssets/1389/1389824_swedish-trends1986-2011-rev121116.pdf)

Widfeldt, A. (2003) The Parliamentary Election in Sweden, 2002. Electoral Studies 22(4): 778-784.

Woolfson, C., Thörnqvist, C. and Sommers, J. (2010) The Swedish Model and the Future of Labor Standards after Laval. Industrial Relations Journal 41(4): 333-350.

epp.eurostat.ec.europa.eu: Internet statistics resource, hosted by the European Commission.

www.scb.se: Website of Statistics Sweden (Statisiska Centralbyrån).

Party manifestos and documents:

Centre-left parties (2010) Socialdemokraternas, Miljöpartiets och Vänsterpartiets $\begin{array}{lll}\text { regeringsplattform 2011-2014. } & \text { Retrieved from }\end{array}$ http://sverigesradio.se/diverse/appdata/isidor/files/83/8839.pdf.

Centre Party (2002) På lika villkor! Centerpartiets valplattform 2002, antagen av förtroenderådet 2002-03-18.

Centre Party (2006) Kontrakt för fler jobb, förnyad väfärd och god miljö. Centrepartiets valmanifest 2006.

Centre Party (2010) Framtiden tillhör den som vågar. Fler jobb i nya och växande företag, förnyad välfärd och god miljö. Valmanifest för Centerpartiet mandatperioden 2010-2014. 
Centre-right parties (2006) Fler i arbete - mer att dela på. Allians för Sverige, valmanifest 2010 .

Retrieved

from

http://www.centerpartiet.se/Documents/rapporter/2006/Fler\%20i\%20arbete\%20\%E2\%80\%9 3\%20mer\%20att\%20dela\%20p\%C3\%A5.pdf.

Centre-right parties (2010) Jobbmanifestet. Alliansen, valmanifest 2010-2014. Retrieved from http://www.alliansen.se/wp-content/uploads/2010/08/VALMANIFEST.pdf.

Christian Democrats (2002) Tid för förändring. Tid för handling. KD valmanifest 2002, antaget av Rikstinget juni 2002.

Christian Democrats (2006) Garantibevis till Dig som väljare inför valet 2006.

Christian Democrats (2010) 13 steg och 89 vallöften för ett mänskligare Sverige. Valmanifest, Kristdemokraterna.

Green Party (2002) Grönt valmanifest 2002 - för en långsiktigt hållbar utveckling.

Green Party (2006) Grönare Sverige - för ökad livskvalitet. Valmanifest 2006.

Green Party (2010) Framtiden är här -- valmanifest för en grön omställning som ger nya jobb, en nödvändig klimatpolitik och global solidaritet.

Left Party (2002) Valplattform 2002.

Left Party (2006) Arbete demokrati rättvisa. Vänsterpartiets valplattform 2006. Retreived from http://orebro.vansterpartiet.se/files/2006/08/valplattform.pdf.

Left Party (2010) Vänsterpartiet, valplattform 2010.

Moderate Party (2002) Frihet för Sverige. Valmanifest 2002.

Liberal Party (2002a) Ett parti som vågar utmana. Folkpartiet liberalernas valmanifest inför valet 2002 . 
Liberal Party (2002b) Nej till rasism och intolerans. Election campaign leaflet (hard copy, owned by author).

Liberal Party (2006) En socialliberal model i globaliseringens tid. Folkpartiets valmanifest $2006 . \quad$ Retrieved from http://www.folkpartiet.se/ImageVault/Images/id_3705/scope_0/ImageVaultHandler.aspx.

Liberal Party (2010) Folkpartiet liberalernas valmanifest 2010. Utmaningar efter valsegern. Retrieved from http://www.folkpartiet.se/ImageVault/Images/id_12208/scope_0/ImageVaultHandler.aspx.

Social Democrats (2002) Tillsammans för trygghet och utveckling. Socialdemokraternas valmanifest 2002-2006.

Social Democrats (2006) Alla ska med. Valmanifest 2006.

Social Democrats (2010). Fler jobb och nya möligheter. Vägval 2010.

Sweden Democrats (2002) Sverigedemokraterna presenterar sitt valmanifest Retrieved from https://www.flashback.org/t7971.

Sweden Democrats (2006) Valmanifest 2006. Antaget vid riksårsmötet den 25 mars 2006. Retrieved from https://herrljunga.sverigedemokraterna.se/2008/11/02/valmanifest_2027/.

Sweden Democrats (2010) 99 förslag för ett bättre Sverige. Sverigedemokraternas kontrakt med väljarna 2010-2014.

Note: Except where otherwise stated, the documents can be retrieved from the Swedish National Data Service (SSD) at Göteborg University (http://snd.gu.se/sv/vivill/party). Some documents can be retrieved from more than one URL address, but they were all retrievable from SSD, or the addresses given above, on 10 March 2013. 
Table 1. Prioritisation of immigration among Swedes, 1987-2011. Per cent respondents naming "immigrants/refugees" as one of the most important "issue(s) or societal problems", and the ranking of immigration among seventeen issue/problem areas. Election years in bold.

\begin{tabular}{|r|r|r|}
\hline Year & Per cent & Rank \\
\hline 1987 & 7 & 10 \\
\hline $\mathbf{1 9 8 8}$ & $\mathbf{8}$ & $\mathbf{9}$ \\
\hline 1989 & 11 & 7 \\
\hline 1990 & 14 & 4 \\
\hline $\mathbf{1 9 9 1}$ & $\mathbf{1 3}$ & $\mathbf{8}$ \\
\hline 1992 & 19 & 4 \\
\hline 1993 & 26 & 3 \\
\hline $\mathbf{1 9 9 4}$ & $\mathbf{1 2}$ & $\mathbf{7}$ \\
\hline 1995 & 14 & 6 \\
\hline 1996 & 13 & 6 \\
\hline 1997 & 10 & 7 \\
\hline $\mathbf{1 9 9 8}$ & $\mathbf{1 0}$ & $\mathbf{8}$ \\
\hline 1999 & 12 & 6 \\
\hline 2000 & 11 & 6 \\
\hline 2001 & 13 & 5 \\
\hline $\mathbf{2 0 0 2}$ & $\mathbf{2 0}$ & $\mathbf{4}$ \\
\hline 2003 & 12 & 6 \\
\hline 2004 & 11 & 7 \\
\hline 2005 & 15 & 6 \\
\hline $\mathbf{2 0 0 6}$ & $\mathbf{1 5}$ & $\mathbf{5}$ \\
\hline 2007 & 14 & 7 \\
\hline 2008 & 13 & 8 \\
\hline 2009 & 15 & 5 \\
\hline $\mathbf{2 0 1 0}$ & $\mathbf{1 9}$ & $\mathbf{4}$ \\
\hline 2011 & 14 & 8 \\
\hline
\end{tabular}

Comment: Based on Weibull et al. 2012:42. Data are from the SOM postal surveys, conducted by Göteborg University (www.som.gu.se). The question is open-ended, with the wording "Which issue(s) or societal problem(s) do you think is/are the most important in Sweden today? Indicate at most three issues/problems". Entries indicate the proportions of respondents mentioning "immigrants/refugees" as one of the up to three issues or problems. The "rank" column reports the ranking of "immigrants/refugees" out of seventeen issue/problem areas. Numbers of respondents vary between 1,573 (1991) and 5,007 (2010). 
Table 2. Immigration and related issues in Swedish parties' election manifestos, 2002-2010.

\begin{tabular}{|c|c|c|c|c|c|c|}
\hline & $\begin{array}{l}\text { Total no. } \\
\text { of words }\end{array}$ & $\begin{array}{l}\text { No. of words on } \\
\text { immigration }(\%)\end{array}$ & $\begin{array}{l}\text { Refugee } \\
\text { immigration }\end{array}$ & $\begin{array}{l}\text { Labour } \\
\text { immigration }\end{array}$ & $\begin{array}{l}\text { Demands } \\
\text { on immigrants }\end{array}$ & $\begin{array}{l}\text { Value statements on } \\
\text { immigration }\end{array}$ \\
\hline SAP 2002 & 2,897 & $189(6.5)$ & 0 & 0 & No & 2 positive \\
\hline SAP 2006 & 4,145 & $153(3.7)$ & 0 & 0 & Yes & 0 \\
\hline SAP 2010 & 2,543 & $41(1.7)$ & 0 & 0 & No & 0 \\
\hline V 2002 & 5,683 & $478(8.4)$ & + & 0 & No & 0 \\
\hline V 2006 & 3,272 & $70(2.1)$ & + & 0 & $\mathrm{No}$ & 0 \\
\hline V 2010 & 2,010 & $20(1.0)$ & 0 & 0 & No & 0 \\
\hline MP 2002 & 1,479 & $88(5.9)$ & + & 0 & No & 0 \\
\hline MP 2006 & 1,847 & $93(5.0)$ & + & 0 & No & 0 \\
\hline MP 2010 & 2,464 & $163(6.6)$ & + & 0 & No & 0 \\
\hline Centre-left 2010 & 4,800 & $93(1.9)$ & + & 0 & No & 0 \\
\hline C 2002 & 2,614 & $61(2.3)$ & 0 & 0 & Yes & 1 positive \\
\hline C 2006 & 4,390 & $139(2.9)$ & 0 & + & Yes & 2 positive \\
\hline C 2010 & 7,082 & $36(0.5)$ & 0 & + & No & 1 positive \\
\hline FP 2002 & 5,736 & $316(5.5)$ & 0 & + & Yes & 1 positive \\
\hline FP 2006 & 15,600 & $1,357(8.7)$ & 0 & 0 & Yes & 0 \\
\hline FP 2010 & 9,800 & $840(8.6)$ & + & + & Yes & 1 positive \\
\hline KD 2002 & 4,671 & $46(1.0)$ & 0 & 0 & No & 0 \\
\hline KD 2006 & 2,125 & $22(1.0)$ & 0 & 0 & No & 0 \\
\hline KD 2010 & 3,365 & $263(7.8)$ & + & 0 & (Yes) & 1 positive \\
\hline M 2002 & 5,744 & $246(4.3)$ & 0 & 0 & Yes & 0 \\
\hline Centre-right 2006 & 11,100 & $638(5.7)$ & 0 & + & No & 1 positive \\
\hline Centre-right 2010 & 17,000 & $602(3.5)$ & 0 & + & No & 1 positive \\
\hline SD 2002 & 755 & $99(13.1)$ & - & 0 & Yes & 0 \\
\hline SD 2006 & 1,664 & $336(20.2)$ & - & 0 & Yes & 2 negative \\
\hline SD 2010 & 1,800 & $217(12.0)$ & - & - & Yes & 0 \\
\hline
\end{tabular}

Comment: SAP = Social Democrats; V = Left Party; MP = Green Party; Centre-left = SAP+V+MP; C = Centre Party; FP = Liberal Party; KD = Christian Democrats; M = Moderate Party;

Centre-right $=\mathrm{C}+\mathrm{FP}+\mathrm{KD}+\mathrm{M}(+)=$ advocacy of more generous policy; $(-)=$ advocacy of more restrictive policy; $0=$ neutral position, or issue not mentioned. Brackets indicate borderline cases

In 2006 and 2010, M did not present separate manifestos. 
Figure 1. Indicators of non-Nordic immigration in Sweden, 1985-2013. Percentages of total Swedish population.

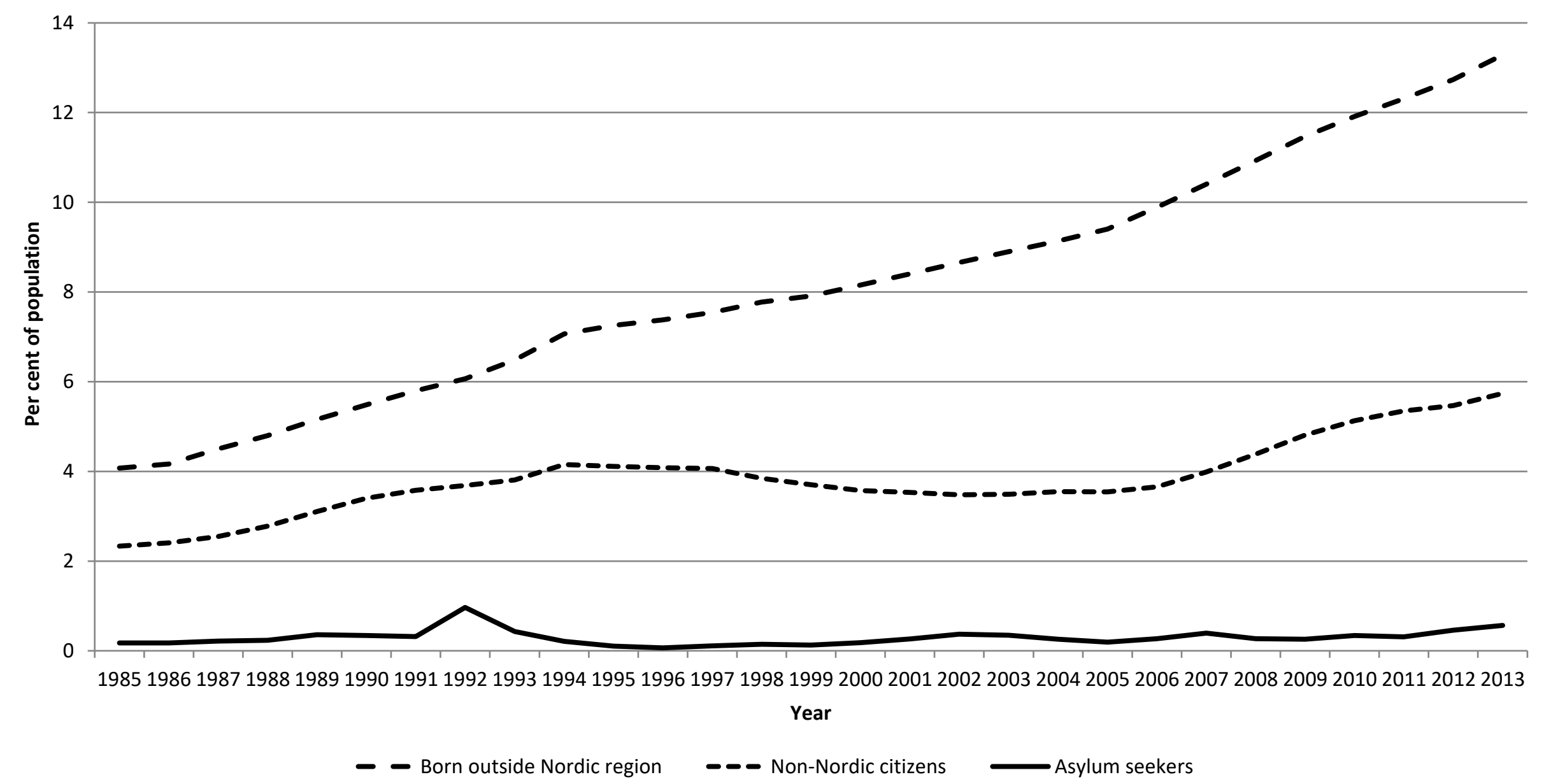

Comment: Nordic refers to Denmark, Finland, Iceland, Norway (and Sweden). Immigrants born in, and/or citizens of, all other countries are included in the data. Sources: www.scb.se (born outside Nordic region and non-Nordic citizens) and http://epp.eurostat.ec.europa.eu/ (asylum seekers). 